\title{
Activity of Enzymes Associated with the Enzymatic Browning of Minimally Processed Potatoes
}

\author{
Maria Carolina Dario Vitti ${ }^{1}$, Fabiana Fumi Sasaki ${ }^{1}$, Patrícia Miguel ${ }^{1}$, Ricardo Alfredo \\ Kluge $^{1 *}$ and Celso Luiz Moretti ${ }^{2}$ \\ ${ }^{I}$ Departamento de Ciências Biológicas; Escola Superior de Agricultura “Luiz de Queiroz”; Universidade de São \\ Paulo, C.P.: 9; 13418-900; Piracicaba - SP - Brasil. ${ }^{2}$ Empresa Brasileira de Pesquisa Agropecuária; 70359-970; \\ Brasília - DF - Brasil
}

\begin{abstract}
The purpose of the present study was to evaluate the effect of different potato cultivars and storage temperatures on the specific activity of phenylalanine ammonia-lyase (PAL), polyphenol oxidase (PPO) and peroxidase (POD) in minimally processed potatoes. Potato cultivars Agata, Asterix and Monalisa were selected, washed, peeled, diced, sanitized, centrifuged, vacuum- packed and stored at 5 and $15^{\circ} \mathrm{C}$ for 9 and 5 days, respectively. There was an increase in the enzymatic activity in all the cultivars stored at $15^{\circ} \mathrm{C}$. The cultivars 'Agata' and 'Asterix' stored at $5^{\circ} \mathrm{C}$ did not differ significantly between them for the PAL, PPO and POD activities. The PAL, PPO and POD activities were also influenced by the storage temperature. The cultivars Agata and Asterix were more suitable in minimal processing than 'Monalisa', which was more susceptible to oxidative browning.
\end{abstract}

Key words: Solanum tuberosum L.; phenylalanine ammonia-lyase; polyphenol oxidase; peroxidase; minimal processing

\section{INTRODUCTION}

Enzymatic browning is one of the most important limiting factors for the postharvest life of many minimally processed vegetables. The intensity of browning is mainly influenced by the oxidative activity and substrate concentration. The main enzymes involved in oxidative reactions of phenolic compounds are polyphenol oxidase (PPO) and peroxidase (POD) (Clemente and Pastore, 1998). According to Saltveit (2000), the increase in the enzymatic activity of phenylalanine ammonia-lyase (PAL), PPO and POD is a response to the stress undergone by tissues while cutting, which leads to decreased shelf-life. Weller et al. (1997) also stated that the surface browning was extremely important when the refrigerated product was to be used in pieces, or shredded, as the contact between the phenols and endogenous PPOs, as well as the easy oxygen diffusion to the inner tissues, led to the surface browning.

Potato is highly nutritious and one of the main products consumed worldwide. It is considered a functional food which, besides its basic nutritional functions, also presents biologically active substances that positively affect the health and reduce degenerative chronic diseases (Machado and Toledo, 2004). However, potato browning after the peeling and cutting is an undesirable alteration and a primary limiting factor for potato

*Author for correspondence: rakluge@esalq.usp.br 
commercialization. The browning degree varies according to the potato cultivar. Moretti et al. (2002) observed that vacuum packed minimally processed sweet potatoes 'Brazlândia Roxa' and 'Brazlândia Branca' stored at $3^{\circ} \mathrm{C}$ were less susceptible to browning than $\mathrm{cv}$ 'Princesa'. Nunes et al. (2001) found that the exposure of the minimally processed product to temperature variations led to an increase in product browning. Temperatures above the recommendation influence the browning degree. Freire Junior et al. (2002) reported that the temperature of $2^{\circ} \mathrm{C}$ was effective in avoiding the browning in minimally processed lettuce until the 10th day of storage, which did not happen at $10^{\circ} \mathrm{C}$.

In view of the factors mentioned above, given the importance of the potato crop for the Brazilian agribusiness and the lack of studies on the enzymatic browning of minimally processed potatoes, the purpose of the present work was to evaluate the effect of different potato cultivars and storage temperatures on the enzymatic metabolism of minimally processed potatoes.

\section{MATERIAL AND METHODS}

Potatoes cv 'Agata', 'Asterix' and 'Monalisa' were obtained from a grower in the Itapetininga region, SP, Brazil. Cultivars were selected according to their firmness, absence of mechanic injuries and fungal infection. Potatoes were prewashed in running water to remove impurities from the field and stored in a cold chamber at $10^{\circ} \mathrm{C}$ before being minimally processed.

The different cultivars were mechanically peeled using an industrial peeler equipped with an abrasive disc and immersed into cooled water $\left(5^{\circ} \mathrm{C}\right)$ for 2 minutes to reduce the metabolism before processing. After that, they were diced using a processor equipped with a $1.0 \times 1.0 \times 1.0 \mathrm{~cm}$ cutting disc and the cut pieces were sanitized for 5 minutes in chlorine water $\left(200 \mathrm{mg} \mathrm{L}^{-1}\right.$ of Sodium Dichloro-S-triazinetrione dehydrate) to reduce the contamination risks. The product was centrifuged at $800 \mathrm{x} \mathrm{g}$ for 10 minutes to drain the excess moisture. Then the samples $(300 \mathrm{~g}$ of product per pack) were vacuum packed in multilayer nylon plastic films $(14 \times 20 \mathrm{~cm})$ and stored at 5 and $15^{\circ} \mathrm{C}$, and $85 \%$ relative humidity. The storage period was 9 and 5 days, and the evaluations were carried out daily for a) activity of phenylalanine ammonialyase - PAL (EC 4.3.1.5), which was determined according to the methodology modified by Peixoto et al. (1999), for which a mixture of $1.0 \mathrm{~mL}$ of extract, $1.0 \mathrm{~mL}$ of $0.2 \mathrm{M}$ borate buffer and $1.0 \mathrm{~mL}$ of phenylalanine was used for the reaction. After incubating at $36^{\circ} \mathrm{C}$ for 60 minutes, $0.1 \mathrm{~mL}$ of $6 \mathrm{~N}$ $\mathrm{HCl}$ was added to stop the enzymatic reaction. The determination was carried out using a spectrophotometer, reading at $290 \mathrm{~nm}$. Results were expressed in mmoles $\min ^{-1}$; b) the activity of polyphenol oxidase (PPO-EC 1.14.18.1), which was determined according to the methodology described by Cano et al. (1997) for which a mixture of $0.3 \mathrm{~mL}$ of crude extract, $1.75 \mathrm{~mL}$ of $0.05 \mathrm{M}$ sodium phosphate buffer $\mathrm{pH} 6$ and $0.05 \mathrm{~mL}$ of $0.1 \mathrm{M}$ catechol solution was incubated at $30^{\circ} \mathrm{C}$ for 30 minutes. After $0.7 \mathrm{~mL} 5 \%$ sulfuric acid was used to stop the enzymatic reaction (adapted from Câmara et al., 2000); the absorbance was read at $395 \mathrm{~nm}$. Results were expressed in $\mu$ moles of transformed catechol $\min ^{-1} \mathrm{~g}^{-1}$; c) activity of peroxidase - POD (EC 1.11.1.9), which was determined according to the methodology adapted from Rossi et al. (1997) for which a mixture of $0.2 \mathrm{~mL}$ of concentrated enzymatic extract with $0.5 \mathrm{~mL}$ of aminoantipyrine and phenol solution and $0.5 \mathrm{~mL}$ of $29 \%$ hydrogen peroxide solution, both diluted in deionized water, was used for the reaction. The determination was carried out using a spectrophotometer, reading at $505 \mathrm{~nm}$. Results were expressed in $\mu$ moles of decomposed $\mathrm{H}_{2} \mathrm{O}_{2}$ $\min ^{-1} \mathrm{~g}^{-1}$; d) soluble proteins, which were determined to calculate the specific activity of the three enzymes evaluated. The Bradford test (1976) was used to quantify the total amount of proteins sampled; e) total phenol amount, which was determined according to the Folin-Ciocalteau method, adapted by Lu and Foo (1997) for which a mixture of $0.1 \mathrm{~mL}$ from each extract was taken and diluted in $50 \mathrm{~mL}$ of distilled water. A $0.5 \mathrm{~mL}$ aliquot was taken and added to $4 \mathrm{~mL}$ of $10 \%$ FolinCiocalteau aqueous solution and $4 \mathrm{~mL}$ of $7.5 \%$ calcium carbonate, the reaction mixture was incubated at $30^{\circ} \mathrm{C}$ for 60 minutes and at $0^{\circ} \mathrm{C}$ for 60 further minutes. A similar procedure was used for the dopamine standard solution and blank solution. The determination was carried out using a spectrophotometer, reading at $760 \mathrm{~nm}$. Results were expressed in $\mu \mathrm{g}$ dopamine $100 \mathrm{~g}^{-1}$ fresh mass. A completely randomized experimental design was used. A $3 \times 9$ factorial design was used for $5^{\circ} \mathrm{C}$ (three cultivars and nine storage periods) and $3 \times 5$ factorial design for $15^{\circ} \mathrm{C}$ (three cultivars and five storage periods). Three replicates of $300 \mathrm{~g}$ of 
minimally processed potatoes were used per treatment.

The enzymatic analyses results were submitted to the minimum significant difference analysis in a multiple comparison test, in which differences between the two treatments higher than the sum of two standard deviations were considered significant at $5 \%$ probability (Shamaila et al., 1992).

\section{RESULTS AND DISCUSSION}

The 'Monalisa' cultivar potatoes stored at $5^{\circ} \mathrm{C}$ showed initially higher PAL activity, which was two times higher than the values observed for others cultivars. After the $3^{\text {rd }}$ day of storage, the PAL activity of 'Monalisa' cultivar reached values near those observed for others cultivars (Fig. 1A). The potatoes stored at $15^{\circ} \mathrm{C}$ cold be stored only for five days, regardless of the treatment, due to the excess water accumulation inside the packaging, which was also responsible for bad smell and a high number of brown spots on the product (Fig.1B). Increased enzymatic activity of PAL was observed for the 'Monalisa' cultivar under both the storage temperatures; at $15^{\circ} \mathrm{C}$ the values were two times higher than others cultivars studied. The PAL activity for all cultivars during the storage period at $15^{\circ} \mathrm{C}$ was stabilized. There was no significant difference between 'Agata' and 'Asterix' cultivars (Fig. 1B).

PAL is the first enzyme in the phenolic metabolism route and has its enzymatic activity triggered by stress conditions. It catalyzes the Lphenylalanine (aromatic amino acid) desamination reaction in trans-cinnamic acid and free ammonia ions. This reaction is the first step of the broad range of reactions that biosynthesizes the phenylpropanoids (Jones, 1984).

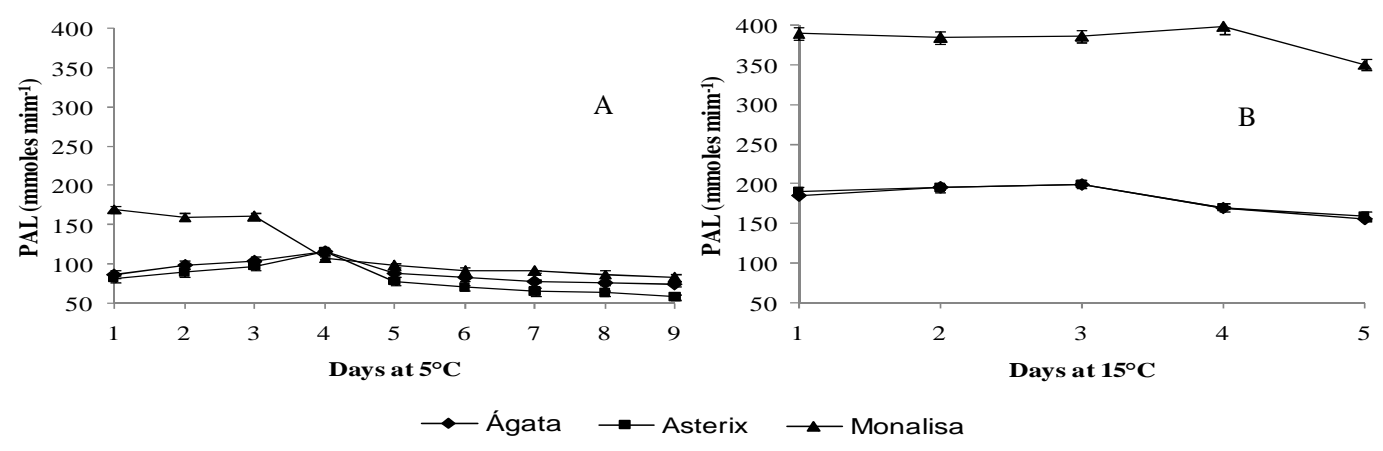

Figure 1 - Phenylalanine ammonia-lyase (PAL) activity in different minimally processed potato cultivars stored at $5^{\circ} \mathrm{C}(\mathrm{A})$ and $15^{\circ} \mathrm{C}(\mathrm{B})$. Vertical bars indicate standard deviation from the mean $(n=3)$.

It has been postulated PAL increases during the minimum processing due to the injuries caused in the cells (Saltveit, 1997). Consequently, the increase in PAL activity promotes an increment in the concentration of phenolic compounds, which are substrates for oxidative enzymes, such as PPO and POD.

Cantos et al. (2002) have observed differences in the PAL activity of five different minimally processed potato cultivars stored at $4^{\circ} \mathrm{C}$. A decline in the enzymatic activity in the Spunta cultivar was observed after 4 days of storage. Similar behavior was observed in the present experiment for 'Monalisa' potatoes stored at $5^{\circ} \mathrm{C}$.

Probably, the higher initial activity of PAL in 'Monalisa' potato could be the high preexisting latent levels of this enzyme in the tissues. The high initial activity of the PAL in 'Monalisa' potato and the increase observed in 'Agata' and 'Asterix' potatoes at $5^{\circ} \mathrm{C}$ probably was the sequential induction of RNAm of this enzyme, as reported in cut potatoes (Ishizuka et al., 1991). Perhaps already the subsequent reduction of the PAL activity (from $5^{\circ}$ day) for all the cultivars was related to the auto-regulation of the metabolic activity.

The higher POD activity was observed for the 'Monalisa' cultivar at both storage temperatures (Fig. 2). No significant differences were found between the 'Agata' and 'Asterix' cultivars at $5^{\circ} \mathrm{C}$ (Fig. 2A). At $15^{\circ} \mathrm{C}$, small changes in POD activity values were observed for all the cultivars during 
the storage period. The POD activity of the $\mathrm{cv}$. Monalisa stored $15^{\circ} \mathrm{C}$ was near to $24 \%$ higher than 'Asterix' and 'Ágata' potato (Fig. 2B).

The high values of POD activity confirmed the induction of the activity of this enzyme under stress conditions. Moreover, there was no formation of brown spots in the treatments with antioxidants solutions, suggesting that peroxidase was not related with the enzymatic browning. Although POD might also contribute to the enzymatic browning, its function is still questionable (Garcia and Barrett, 2002). Pinelli et al. (2006) also reported that the POD activity in minimally processed 'Monalisa' potato at $5^{\circ} \mathrm{C}$ was higher than the activity observed in 'Agata' potato.

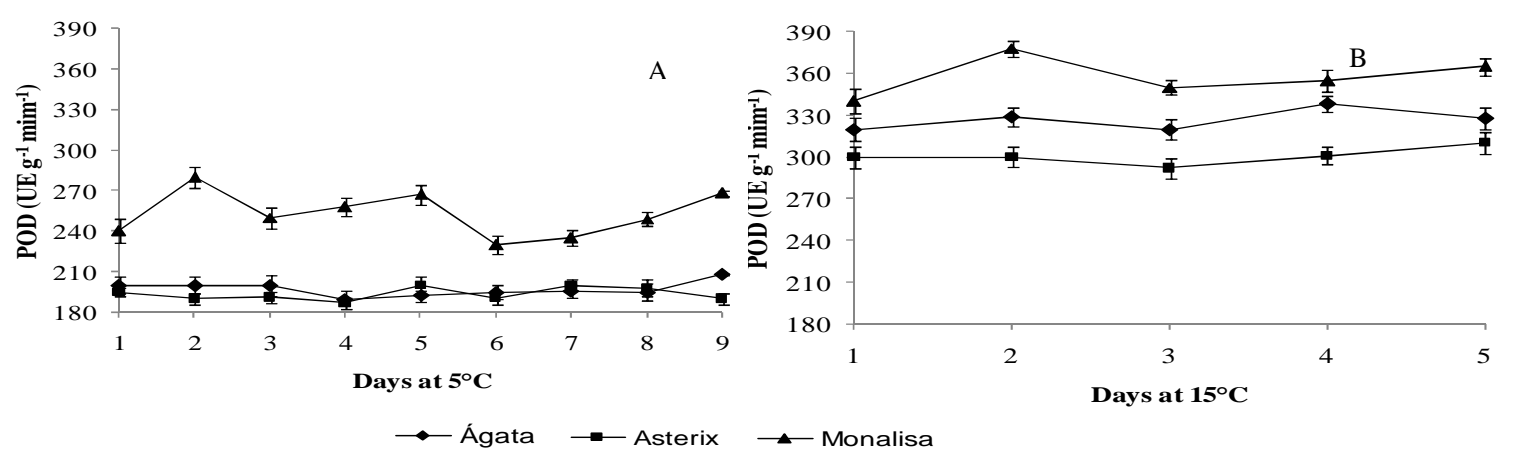

Figure 2- Peroxidase (POD) activity in different minimally processed potato cultivars stored at $5^{\circ} \mathrm{C}(\mathrm{A})$ and $15^{\circ} \mathrm{C}(\mathrm{B})$. Vertical bars indicate standard deviation from the mean $(n=3)$.

It was observed that the behavior of the PPO was similar to the POD at the same temperature (Figura 3A). The 'Monalisa' potato showed the higher activity of PPO during the storage period, being approximately $16 \%$ higher compared to the others cultivars. There was no significant difference for 'Agata' and 'Asterix' cultivars during the storage period.

At $15^{\circ} \mathrm{C}$, the 'Agata' and 'Monalisa' potatoes presented no significant difference in the $2 \mathrm{nd}$, 3rd and 4th day of storage. The 'Asterix' potato showed the lower values of PPO until the 4th day of storage; on the last day, there was an increase in the values of PPO, but it was not significantly different from 'Agata' potato (Figure 3B).Pinelli et al. (2006) found opposite results for PPO activity. They reported that 'Monalisa' potato showed a lower increment in the PPO activity at 5 and $15^{\circ} \mathrm{C}$, when compared to potatoes 'Agata' potato. Zorzella et al., (2003) studying the physicochemical and sensorial characterization of different genotypes of processed potatoes chips, also observed differences in the enzymatic activity of polyphenol oxidase in different cultivars. The results obtained were similar to those found in the present study. In general, , the apparent lack of correlation between the PPO activity and browning susceptibility in minimally processed potato agreed with previous studies, which reported the same poor correlation in potato tubers (Starck et al., 1985). The same lack correlation between the PPO activity and browning in the minimally processed lettuce has been reported previous studies (Cantos et al., 2001). Almeida (2005) found higher activity values for the PPO and POD in minimally processed 'Asterix' and 'Binjte' potato when compared to those found in the present research.

The stress promoted by the operations of peeling and cutting can result higher values of the POD activity; however, this enzyme would not have a bigger involvement with the browning. The activity of the POD in the process of enzymatic browning has been questioned due to the low amount of hydrogen peroxide in the cells of the fruits and vegetables. However, it can have a synergistic effect on PPO and POD, due to hydrogen peroxide release in the oxidation of some phenolic composites, catalyzed for the PPO (Subramanian et al., 1999).

Cell decompartimentalization involves a chain of events, including the activation of latent PPO or "de novo synthesis" of this enzyme, as well as the induction of POD (Hyodo et al., 1991).

Mechanical injuries may induce the "de novo synthesis" of PAL. Cantos et al. (2001) reported the activation of PAL and POD and the 
appearance of the PPO and POD isoforms in cut lettuce cultivars.

Cantos et al. (2002) evaluated the effect of minimum processing on the enzymatic activity of PAL, POD and PPO in five potatoes cultivars. The authors did not find any significant correlation between the browning and any of the variables studied. However, the increase in the POD activity corroborated the induction of the enzymatic activity in response to stress situations. The authors suggested that further studies (membrane stability, calcium amount and proteases activity) would be necessary for a better understanding of the limiting factors that triggered browning in the minimally processed potatoes. The same authors, when studying the enzymatic browning, found that 'Monalisa' potato were more susceptible to browning and did not recommend this cultivar for the minimal processing.
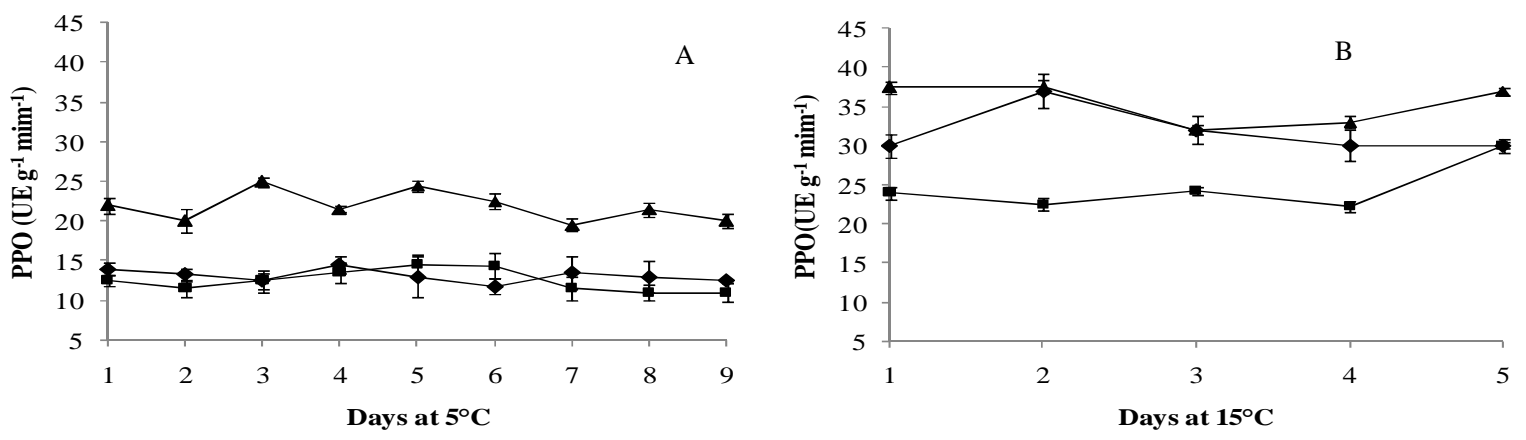

Figure 3- Polyphenol oxidase (PPO) activity in different minimally processed potatoes cultivars stored at $5 \mathrm{oC}(\mathrm{A})$ and $15 \mathrm{oC}(\mathrm{B})$. Vertical bars indicate standard deviation from the mean $(\mathrm{n}=3)$.

Total phenol amount was higher in the 'Monalisa' cultivar at 5 and $15^{\circ} \mathrm{C}$ (Figure 4). A small increase in the phenol amount after the first day of storage was also observed in all the treatments. 'Agata' and 'Asterix' potatoes did not significantly differ between them at both the storage temperatures. At $15^{\circ} \mathrm{C}$, a slight increase in total phenol amount was observed in all the cultivars. The 'Monalisa' cultivar showed two times higher phenols that the 'Agata' and 'Asterix' cultivars (Figure 4B).
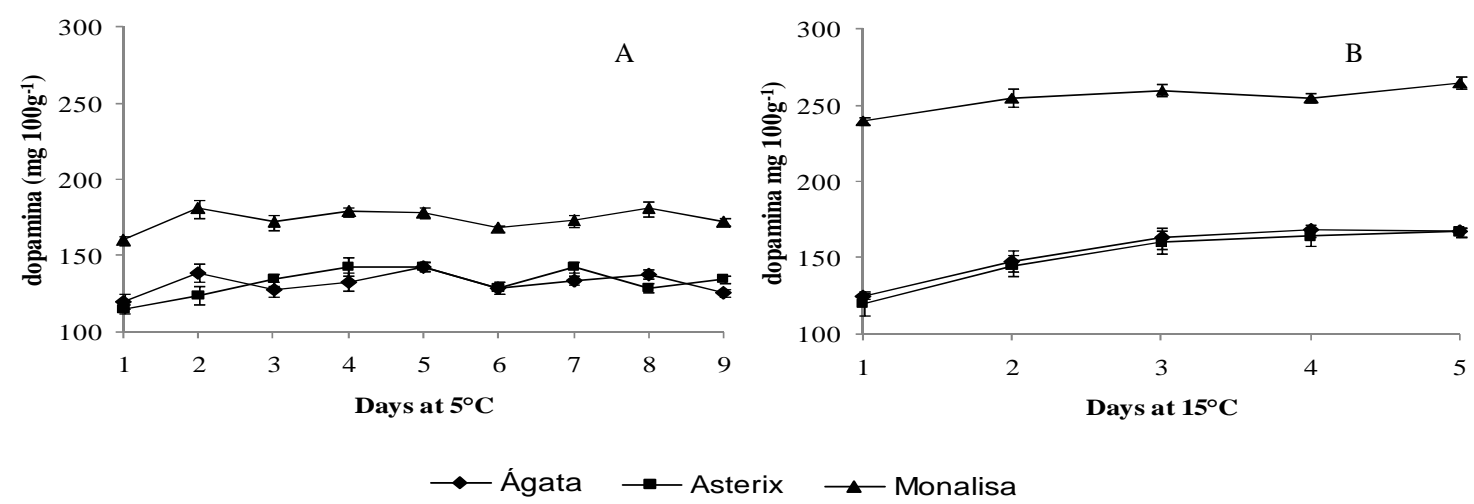

Figure 4 - Total phenol amount in different minimally processed potato cultivars stored at $5^{\circ} \mathrm{C}(\mathrm{A})$ and $15^{\circ} \mathrm{C}(\mathrm{B})$. Vertical bars indicate standard deviation from the mean $(\mathrm{n}=3)$. 
Phenols are secondary metabolic compounds present in vegetables and synthesized in the shikimic acid pathway. These compound present different chemical structures as well as different biological properties and can influence the appearance, change flavor, texture and safety of processed food (Robinson, 1991). Cold storage shows positive and negative effects on the phenol formation. In some cases, low temperatures show beneficial effects and increase anthocyanin amounts in strawberries. During the processing, the increase in the phenolic compounds can increase tissue browning in some products (Tomás-Barberán and Espín, 2001). Phenolic compounds are the substrates of oxidative enzymes (PPO and POD). PPO can oxidize several substrates, including dopamine (Yang et al., 2000). The phenolic compounds may be involved in the growth regulation of potato tubers, as well as in the resistance mechanisms to diseases and insects, and in the metabolism of plants submitted to physiological, or mechanical stresses. Dao and Friedman (1992) reported that phenolic concentrations varied between 100 and $900 \mathrm{mg}$ dopamine $100 \mathrm{~g}^{-1}$ of potato (wet weight), showing that the phenolic concentrations found in the present work were within the variation limits and were a non-desirable characteristic, as phenolic compounds were the substrates of oxidative enzymes (PPO and POD) responsible for the enzymatic browning of potatoes genotypes.

Rocha et al. (2003) observed increased total phenol amounts after one day of storage in the minimally processed potatoes cv 'Desireé'. Ke and Saltveit (1989) found that cutting procedures in the lettuce leaves led to an increase in the total phenol amount. Howard and Griffin (1993) observed that increases in the phenol amount of minimally processed carrots were related to the increase in the PAL activity under the stressful conditions.

The present study showed difference in the degree of susceptibility to stress between the cultivars studied. The 'Monalisa' potato showed high activity of the PAL, consequently, caused higher accumulation of total phenols and it had higher activity of POD and PPO. The high initial activity of the PAL in the 'Monalisa' potato in relation the others cultivars studied also could have the higher amount of latent PAL present in the tissues of the 'Monalisa' potato genotype. It was observed that the lower temperature of storage contributed significantly to keep the quality of minimally processed potatoes, independent of the cultivars, and for the reduction in the activity of enzymes the PAL, POD and PPO and in total phenol amounts. The enzymatic browning is a serious problem in minimum processing. In intact potato cells, the oxidative enzymes and phenolic substrates are spatially apart from each other. As soon as cells are broken, these enzymes and substrates mix, leading to the formation of undesirable colors in the products. The enzymatic browning not only leads to undesirable colors, but may also lead to the loss of nutritional quality and flavor changes. In the present study, potatoes stored at $5^{\circ} \mathrm{C}$ showed visually better quality during the storage. The cultivars 'Agata' and 'Asterix' stored at $5^{\circ} \mathrm{C}$ did not significantly differ for PAL, PPO and POD activities. Minimally processed 'Monalisa' potato stored at $15^{\circ} \mathrm{C}$ showed PAL values twice higher than other cultivars. PPO and POD activities were also higher in this cultivar. The lower susceptibility to the enzymatic browning shown by the 'Agata' and 'Asterix' cultivars stored at $5^{\circ} \mathrm{C}$ implied that these cultivars were more appropriate for minimum processing than 'Monalisa' cultivar. The enzymatic browning is a negative and complex phenomenon in minimally processed potatoes. Further studies on the effective enzymatic action and on the action of the phenolic compounds linked to the browning process, as well as the analysis of isoforms and oxidative routes, are necessary. Other aspects, such as the use of new cultivars, modified atmosphere and edible coating should also be explored.

\section{ACKNOWLEDGEMENTS}

The authors thank "FAPESP -Fundação de Amparo à Pesquisa do Estado de São Paulo", for providing financial resource for the execution this experiment (proc. $\mathrm{n}^{\circ}$ 2005/02332-4) and "Conselho Nacional de Desenvolvimento Científico e Tecnológico" (CNPq), for providing the fellowship to main author and CAPES, for providing the fellowship to first author.

\section{REFERENCES}

Almeida, G.C. (2005). Qualidade de batatas palito minimamente processadas. Dissertação Mestrado.Universidade Federal de Lavras, Lavras, Brasil. 
Bradford, M. (1976). A rapid and sensitive method for the quantitation of microgram quantifies of protein utilizing the principle of protein-dye binding. Analytical Biochem.,72, 248-254.

Câmara, F. L. A., Vilhena, S. M. C., Kruger, F.G.Q., Lima, G. P. P. (2000). Atividades de peroxidase e polifenoloxidase durante o armazenamento de yacon. Hortic. Bras., 18 (1), 888-889.

Cano, M.P., de Ancos, B., Matallana, M.C., Camara, M., Reglero, G., Tabera, J. (1997). Differences among spanish and latin-american banana cultivars: morphological, chemical and sensory characteristics. Food Chem., 59, 411-419.

Cantos, E., Espín, J.E.,Tomás-Barberán, F.A., (2001). Effect of wounding on phenolic enzymes in six minimally processed lettuce cultivars upon storage. J. Agric. and Food Chem., 49, 322-330.

Cantos, E., Tudela, J.A., Gil, M.I., Espin, J.C. (2002). Phenolic compounds and related enzymes are not rate-limiting in brownig development of fresh cut potatoes J. Agric. and Food Chem, 50, 3015-3023.

Clemente, E., Pastore, G.M. (1998). Peroxidase and polyphenoloxidase, the importance for food technology. Boletim SBCTA, 32, 167-171.

Dao, L., Friedman, M. (1992). Chlorogenic acid content of fresh and processed potatoes determined by ultraviolet spectrophotometry. J. Agric. and Food Chem, 40, 2152 - 2158.

Freire Junior, M., Deliza, R., Chitarra, A.B. (2002). Alterações sensoriais em alface hidropônica cv. Regina minimamente processada e armazenada sob refrigeração. Hortic.Bras., 20, 63-66.

Garcia, E., Barrett, D. M. (2002). Preservative Treatments for Fresh-cut Fruits and Vegetables. In O. Lamikanra, (pp. 268-303). Fresh-cut Fruits and Vegetable. Florida: CRC Press.

Hyodo, H., Tanaka, K., Suzuki, T. (1991). Wound induced ethylene synthesis and its involvement in enzyme induction in mesocarp tissue of Curcurbita maxima. Postharvest Biol. and Technol. 1, 127 - 136.

Howard, L.R., Griffin, L.E. (1993). Lignin formation and surface discoloration of MP carrot sticks. J. Food Sci., 58, 1065-1067.

Ishizuka, M., Yamada, F., Tanaka, Y., Takeuchi, Y., Tmaseki, H. (1991). Sequential induction of mRNA for phenylalanime ammonia-lyase in slices of potato tuber. Plant and Cell Physiol., 32, 57-64.

Jones, H. D. (1984). Phenylalanine ammonia lyase: regulation of its induction, and its role in plant development. Phytochem, 23, 1349-1355.

Ke, D., Saltveit, M.E. (1989). Wound induced ethylene production, phenolic metabolism and susceptibility to russet spotting in iceberg lettuce. Plant Physiology, 76, 412-418.
Lu, Y., Foo, L.Y. (1997). Identification and quantification of major polyphenols in apple pomace. Food Chem., 59, 187-194.

Machado, R.M.D., Toledo, M.C.F. (2004). Determinação de glicoalcalóides em batatas in natura comercializadas na cidade de Campinas, Estado de São Paulo. Ciênc. Tecnol. Alimentos, 24, 47-52.

Moretti, C.L., Araujo, A.L., Marouelli, W.A., Silva, W.L.C. (2002). Respiratory activity and browing of minimally processed sweetpotatoes. Hortic. Bras., 20, 497-500.

Nunes, M.C.N., Emond, J.P., Brecht, J.K. (2001). Temperature abuse during ground and inflight handling operations affects quality os snap beans. HortScience, 36, 510.

Peixoto, P.H.P., Cambraia, J., Sant'Anna, R., Mosquim, P.R., Moreira, M.A. (1999). Aluminium effects on lipid peroxidation and the actives of enzymes of oxidative metabolism in sorghum. Rev. Bras. Fisiol. Vegetal, 11, 137-143.

Pinelli, L.L.O, Moretti, C.L., Almeida, G.C., Santos, J.Z., Onuki, A.C.A., Nascimento, A.B.G. (2006). Caracterização química e física de batatas Ágata e Monalisa minimamente processadas. Ciência e Tecnologia de Alimentos, 26, 127-134.

Robinson, D.S. (1991). Peroxidases e Catalases in Foods. In D. S. R. Robinson, N. A. M. Eskin, Oxidative Enzymes in Foods, (pp. 1-47) London: Elsevier.

Rocha, A.M.C.N., Coulon, E.C., Morais, A.M.M.B. (2003). Effects of vacuum packging on the physical quality of minimally processed potatoes. Food Service and Technology, 3, 81-88.

Rossi, C., Lima, G.P.P., Hakvoort, D. M. R. (1997). Ativiade de Peroxidases (EC 1.11.1.7) e teor de prolina em feijoeiro Phaseolus vulgaris L. Cultivado em condições de salinidade, Scientia Agricola, 54 (3), 123-127.

Saltveit, M.E. (1997). Phsical and Physiological Changes in Minimally Processed Fruits and Vegetable. In F. A. Tomás-Barberán, R. D. Robin, Phytochemistry of Fruits and Vegetables, (pp. 205220). Oxford: Oxford University Press.

Saltveit, M.E. (2000). Wound induced changes in phenolic metabolism and tissue browing are alterad by heat shock. Postharvest Biol. and Techno., 21, 6169.

Shamaila, M., Powrie, W.D., Skura, B.J. (1992). Sensory evalution of strawberry fruit stored under modified atmosphere packaging (MAP) by quantitative descriptive analysis. .J. Food Science, 57, 1168-1172. 
Starck, J.C., Corsini, D.L., Hurley, P.J., Dwelle, R.B. (1985). Biochemical characteristics of potato clones differing in blackspot susceptibility. American Potato Journal, 62, 657-666.

Subramanian, N., Venkatesh, P., Ganguli, S., Sinkar, V. P. (1999). Role of poliphenol oxidase and peroxidase in the generation of black tea theaflavins. J. Agric. and Food Chem, 47, 2571- 2578.

Tomás-Barberán, F.A., Espín, J.E. (2001). Phenolic compounds and related enzymes as determinants of quality in fruits and vegetables. J. Agric. and Food Chem, 81, 853-876.
Weller, A., Sims, C.A., Matthews, R.F., Bates, R.P., Brecht, J.K. (1997). Browning susceptibility and changes in composition during storage of carambola slices. J. Food Science, 62, 256-260.

Yang, C.P., Fujita, S., Ashrafuzzman, M.D., Nakamura, N., Hayashi, N. (2000). Purification and characterization of polyphenol oxidase from banana (Musa sapientum L.) pulp. J. Agric. and Food Chem, 48, 2.732-2.735.

Zorzella, C. A., Vendruscolo, J. L. S., Treptow, R. O., Almeida, T. L. (2003). Caracterização física, química e sensorial de genótipos de batata processados na forma de chips. Braz. J. Food Technol., 6, 15-24. 